\title{
Drought Consequences for Cow-Calf Production in Wyoming: 2011-2014
}

\author{
By John D. Scasta, Jessica L. Windh, Travis Smith, and Bob Baumgartner
}

\section{On the Ground}

- Drought reduces forage quantity and carrying capacity, but reductions in cow-calf performance measured by calf average daily gain (ADG) and weaning weight (WW) are less understood.

- From 2011 to 2014 , a period with very dry and very wet years, we assessed an adjusted 210 day WW and ADG for a total of 869 calves on two University of Wyoming ranches.

- We found WW was up to 99 pounds (lb) lower, and ADG was up to $0.47 \mathrm{lb}$ lower between the driest and wettest years.

- For each one inch reduction in precipitation, WW are predicted to be $7 \mathrm{lb}$ to $14 \mathrm{lb}$ lower, ADG is expected to be $0.03 \mathrm{lb}$ to $0.07 \mathrm{lb}$ lower, and dollar per head values $\$ 12$ to $\$ 27$ lower, depending on calf sex and ranch location.

- If drought occurs, or continues to escalate in frequency and severity, WW reductions, ADG reductions, and value per head reductions should be expected and documented for strategic planning and/or compensation programs.

Keywords: beef, climate, precipitation, weaning weights, weather.

Rangelands 37(5):171-177

doi 10.1016/j.rala.2015.07.001

(C) 2015 The Society for Range Management

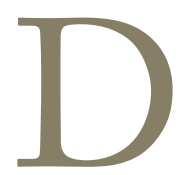

rought is a constant challenge to livestock production on western rangelands. The early twenty-first century resembled the extreme droughts of the 1930s "dust bowl" and the 1950s drought in the southwestern United States ${ }^{1}$ and caused many ranches to reduce herds or go out of business completely. Drought has been defined as a period when precipitation is consistently less than what is climat- ically expected. The magnitude or severity of drought can be characterized three ways, including (1) persistence, (2) intensity or deficit severity, and (3) the interval between events. ${ }^{2}$ The most common way that drought impacts livestock production is the reduction of forage quantity and carrying capacity relative to animal demand; an effect that typically leads to herd reduction or complete liquidation. Although the problematic reduction of forage quantity leading to reduced animal numbers is well understood, what may be less understood is its negative effect on forage quality and subsequent livestock performance. Even when ranches are stocked to absorb the variation in precipitation and reduction in forage quantity, ranchers may not fully recognize and quantify the potential negative effects of the low-quality forage as it influences cow nutrient requirements and optimal calf growth.

\section{The Situation}

The drought of 2011 and 2012 was noted as one of the worst droughts in North America in recorded history. ${ }^{3}$ Droughts such as these often result in losses from the liquidation of cows from the herd due to reduced forage quantity. ${ }^{4}$ However, severe drought also reduces the nutritive value of grasses, causing deleterious effects on forage quality through reduced crude protein and higher acid detergent fiber. ${ }^{5}$ Thus, the reduced nutritive value of drought-stricken forage on rangelands is reflected in lower protein and energy and, consequently, lower cow and calf performance.

\section{Cattle and Rangeland Management Description}

This study was conducted on two University of Wyoming Agricultural Experiment Station (AES) ranches in the northern mixed prairie of southeastern Wyoming, an area with a semi-arid climate. The Sustainable Agriculture Research and Extension Center (SAREC) ranch is located 
northwest of Lingle, Wyoming, in Goshen County. The SAREC ranch comprises 1,880 acres of native rangeland dominated by sagebrush (Artemisia spp.); native cool-season grasses, such as western wheatgrass (Pascopyrum smithii) and needle-and-thread (Hesperostipa comata), with a minor component of warm-season grasses, such as blue grama (Bouteloua gracilis), buffalograss (Bouteloua dactyloides), little bluestem (Schizachyrium scoparium), sand bluestem (Andropogon hallii), and sand dropseed (Sporobolus cryptandrus); and improved forages, such as crested wheatgrass (Agropyron cristatum). Soils comprise sand, loam, and shallow loam. Average elevation at SAREC is 4,104 feet, with approximately 300 feet in elevation change due to steep bluffs. During the study period, mean \pm standard error (SE) stocking rate for SAREC was $0.31 \pm 0.06$ animal unit months (AUMs) per acre, and stocking rate was reduced after the 2012 drought from 0.43 to 0.21 AUMs per acre. SAREC uses extensive (as opposed to intensive) rotational grazing, basing cattle movements across six pastures, depending on available forage and cattle are on the ranch for the entire year. SAREC uses natural service for two to three heat cycles at a bull/cow ratio of 1:20-25. On average, 44 calf weights per year were collected for our study from the SAREC ranch. The average birth weight (BW) was $85 \mathrm{lb}$, the average weaning weight (WW) was $534 \mathrm{lb}$, the average birth date was March 16, and the average weaning date was September 30. SAREC calves were sorted and weighed the day of weaning. Weights were collected at SAREC by using an LBS scale system that is part of the squeeze chute, so weights were collected as calves were processed.

The McGuire ranch is part of the Laramie AES Beef Unit located north of Laramie, Wyoming, in Albany County. The McGuire ranch comprises 5,550 acres of native rangeland dominated by sagebrush; native cool-season grasses, such as bluebunch wheatgrass (Pseudoroegneria spicata), streambank wheatgrass (Elymus lanceolatus), green needlegrass (Nassella viridula), western wheatgrass, and needle-and-thread; and a minor component of improved forages, such as crested wheatgrass and Russian wildrye (Psatbyrostachys juncea). Soils are highly variable and include shallow loam, coarse upland, saline, and impervious clay. Average elevation at McGuire is 7,165 feet, with greater than 450 feet in elevation change due to rocky outcropping complexes. During the study period, mean \pm SE stocking rate for McGuire was $0.14 \pm 0.01$ AUMs per acre, and stocking rate was reduced after the 2012 drought from 0.14 to 0.12 AUMs per acre. McGuire uses seasonal continuous grazing during the growing season, with all cattle having access to the entire ranch, with the exception of small holding paddocks near the shipping corrals. McGuire uses synchronized heat for artificial insemination (AI) for all cows, followed by 45-day exposure to cleanup bulls (i.e., three heat cycles) at a bull/cow ratio of 1:20. On average, 174 calf weights per year were collected for our study from McGuire. Cows calve at the Beef Unit at Laramie, Wyoming, and then are moved to McGuire in June for summer grazing. The average BW was $85 \mathrm{lb}$, the average WW was $555 \mathrm{lb}$, the average birth date was March 17, and the average weaning date was October 8. McGuire calves were sorted, loaded, and trucked to the Beef Unit headquarters to be weighed the same day or the day immediately after weaning. Weights were collected by using an independent aluminum platform with a Tru-Test XR3000 unit placed in the alley before the calves proceeded through the squeeze chute for additional processing.

The McGuire Ranch serves as the genetic foundation herd for SAREC, and cows at both ranches were Angus or Angus x Gelbvieh (Bos taurus). Average cow age for both ranches was estimated to be 7 years through the study period. McGuire used semen from nine bulls for AI during the study period, with average breed expected progeny differences (EPD) for WW (mean $\pm \mathrm{SE}$ of $49 \pm 3$ ) and yearling weight (YW; $82 \pm 5$ ). SAREC used breed representative bulls for natural service. Given the control of sires, any variation in growth potential of calves is not attributed to variability of heritable growth traits from bulls.

\section{Objectives and Outcomes}

Our objective for this study was to understand how WW and ADG could be predicted by annual variation in precipitation in Wyoming. We anticipate that this information will provide three applied outcomes: (1) provision of data for ranchers to forecast calf performance consequences caused by drought, (2) quantification and prediction of the potential economic consequences of escalating drought prevalence in the western Great Plains, and (3) documentation of these negative consequences in a peer-reviewed format to provide a reference for ranchers seeking compensation.

\section{How We Analyzed the Data}

We used the calf WW and ADG from both ranches as the metric of cow production. Because of variability in birth dates and weaning dates, we adjusted WW to a 210 -day value by calculating "total gain" (WW - BW), "days gaining weight" (weaning date - birth date), "ADG" (total gain $\div$ days of gaining weight), and then multiplied ADG by 210 days to calculate the final 210-day adjusted WW. We then calculated the mean and standard error of the adjusted WW separately by calf sex (steer and heifer calves) for each ranch location and each year. Because our data are limited to two weights per calf (BW and WW), the adjusted WW assumes that ADG is linearly related to time, so we also calculated and analyzed the mean and standard error of ADG (i.e., pounds of gain per head per day) in a similar fashion.

We graphed the mean and standard error of the adjusted WW and ADG by calf sex relative to the cumulative precipitation from January 1 to October 1 to assess the relationships in cow production along the drought gradient. We then used linear least squares regression to fit a trendline to the graphed points. We calculated the coefficient of determination $\left(r^{2}\right)$ to understand how well the fit trendline explained the variation and assessed a $P$ value for significance. We assessed the slope of the linear equation for each scenario to predict how many pounds of adjusted WW and ADG may be lost per one-inch reduction in cumulative precipitation. We also used analysis of variance (ANOVA) at the $95 \%$ confidence level (CI) 
to compare annual WW and ADG means separately for steers and heifers for each ranch. Using cumulative precipitation from January 1 to October 1 for each year as the measure of drought, we sought to quantify the magnitude of annual deviation from the mean cumulative precipitation. Therefore, we converted inches of precipitation to a standardized $Z$ index relative to the 15 -year mean (the period of record) by subtracting the mean and dividing by the standard deviation.

We estimated economic losses attributed to drought-induced reductions in WW and marketable beef products for the two terminal cow-calf operations by using price data from the November 10, 2014 USDA-Wyoming cattle market report, which includes multiple sale reports from local auction markets in Torrington, Wyoming, and Riverton, Wyoming. ${ }^{6}$ These sale reports were used to determine the linear weight/price relationship for medium and large \#1 feeder steers and heifers separately (i.e., a price slide accounting for heavier calves bringing fewer dollars per pound than lighter calves). Using the slope to predict how many pounds of adjusted WW and ADG may be lost per one-inch reduction in cumulative precipitation (calculated above) we forecasted WW and ADG along the drought gradient to compare losses for the (1) 2012 drought compared with the 4-year mean and (2) per one-inch reduction in cumulative precipitation. For these two scenarios, we then calculated dollar losses per head, dollar losses per herd, and total pounds of weaned beef lost for each ranch and calf sex separately. An assumption in these calculations was that prices would remain steady during drought events, but in all likelihood, drought could induce greater supply of cattle hitting the market and result in a price reduction - an effect that would increase potential droughtinduced economic losses. ${ }^{7}$ Furthermore, the calculations only quantify economic losses attributed to reductions in calf WW or ADG and do not account for herd reduction - an assumption that could hold for a conservatively stocked ranch. We contend that by holding all other parameters constant (i.e., droughtinduced price variation, ranch base herd numbers, etc.), our assumptions provide a reliable estimate of only drought-induced reductions from lower cow and calf performance.

\section{Results}

\section{Drought}

The mean precipitation from January 1 to October 1 (henceforth growing season precipitation) annually from 1999 to 2014 was 9.9 inches for SAREC and 7.6 inches for McGuire. The wettest year for both locations was 2014 with growing season precipitation of 16.4 and 11.1 inches, respectively. Based on the 15-year growing season precipitation mean for both locations and drought magnitude, 2012 was the second driest year for SAREC (1999 was drier) and the driest year for McGuire (Fig. 1). The drought appeared to develop earlier at McGuire, beginning in 2010 and persisting for 3 years, and later for SAREC, beginning in 2012 and persisting for 2 years. The magnitude of the drought relative to the 15-year mean and the duration of the drought were both greater for McGuire than SAREC (see Fig. 1).

\section{Weaning Weight}

Adjusted WW were lowest at both locations in 2012, the worst drought year during the study, and were significantly lower than the wettest years ${ }^{i}$ (Fig. 2). During this drought year, at SAREC, steers and heifers averaged $473 \mathrm{lb}$ and $425 \mathrm{lb}$ respectively; and at McGuire ranch, steers and heifers averaged $447 \mathrm{lb}$ and $426 \mathrm{lb}$, respectively. In contrast, WWs were highest at both locations in 2014, the wettest year during the study $(P \leq$ 0.05; see Fig. 2). During this wet year, at SAREC, steers and heifers averaged $547 \mathrm{lb}$ and $514 \mathrm{lb}$, respectively; and at McGuire ranch, steers and heifers averaged $546 \mathrm{lb}$ and $508 \mathrm{lb}$, respectively. The range of WWs between the driest and wettest years ranged from 74 to $99 \mathrm{lb}$ for steer calves and 89 to $82 \mathrm{lb}$ for heifer calves at SAREC and McGuire ranch, respectively.

At both locations, the onset of drought resulted in a decrease in WW (see Fig. 2). Based on the slope, the decrease is greater at McGuire than at SAREC. At McGuire, steers and heifers can be expected to wean almost $14 \mathrm{lb}$ and $11 \mathrm{lb}$ lighter for every one-inch decrease in precipitation, but at SAREC, steers and heifers can be expected to wean approximately $7 \mathrm{lb}$ and $8 \mathrm{lb}$ lighter for every one inch decrease in precipitation (Table 1). The linear relationship predicting reduced WWs along the drought gradient was significant ${ }^{\mathrm{ii}}$ and highly correlative ${ }^{i i i}$ in all cases (see Table 1).

\section{Average Daily Gain}

The effect of declining precipitation demonstrated for adjusted WW above was similar for calf daily gains because the adjusted WW assumes a linear relationship between total gain and time. ADG was lowest at both locations in 2012, the worst drought year during the study ${ }^{\text {iv }}$ (see Fig. 2). During this drought year, at SAREC, steers and heifers averaged daily gains of $2.26 \pm 0.06 \mathrm{lb}$ and $2.03 \pm 0.05 \mathrm{lb}$, respectively; and at McGuire, steers and heifers averaged daily gains of $2.13 \pm$ $0.04 \mathrm{lb}$ and $2.03 \pm 0.02 \mathrm{lb}$, respectively. In contrast, ADG were highest at both locations in 2014, the wettest year during the study ${ }^{\mathrm{v}}$ (Fig. 2). During this wet year, at SAREC, steers and heifers averaged daily gains of $2.61 \pm 0.04 \mathrm{lb}$ and $2.45 \pm$ $0.03 \mathrm{lb}$, respectively; and at McGuire, steers and heifers averaged daily gains of $2.60 \pm 0.03 \mathrm{lb}$ and $2.42 \pm 0.03 \mathrm{lb}$, respectively. The ADGs between the driest and wettest years ranged from 0.35 to $0.47 \mathrm{lb}$ for steer calves and 0.42 to $0.39 \mathrm{lb}$ for heifer calves at SAREC and McGuire, respectively.

At both locations, drought resulted in a decrease in ADG (see Fig. 2). Based on the slope, the decrease for both was greater at McGuire than SAREC. At McGuire, steers and heifers can be expected to lose $0.06 \mathrm{lb}$ to $0.07 \mathrm{lb}$ of ADG for every one-inch decrease in precipitation, but at SAREC, steers and heifers can be expected to lose $0.03 \mathrm{lb}$ to $0.04 \mathrm{lb}$ of ADG for every one-inch decrease in precipitation (see Table 1). The linear relationship

\footnotetext{
${ }^{\text {i }} P \leq 0.05$.

ii $P \leq 0.05$.

iii $r^{2}=0.91$ to 0.97 .

iv $P \leq 0.05$.

${ }^{v} P \leq 0.05$.
} 


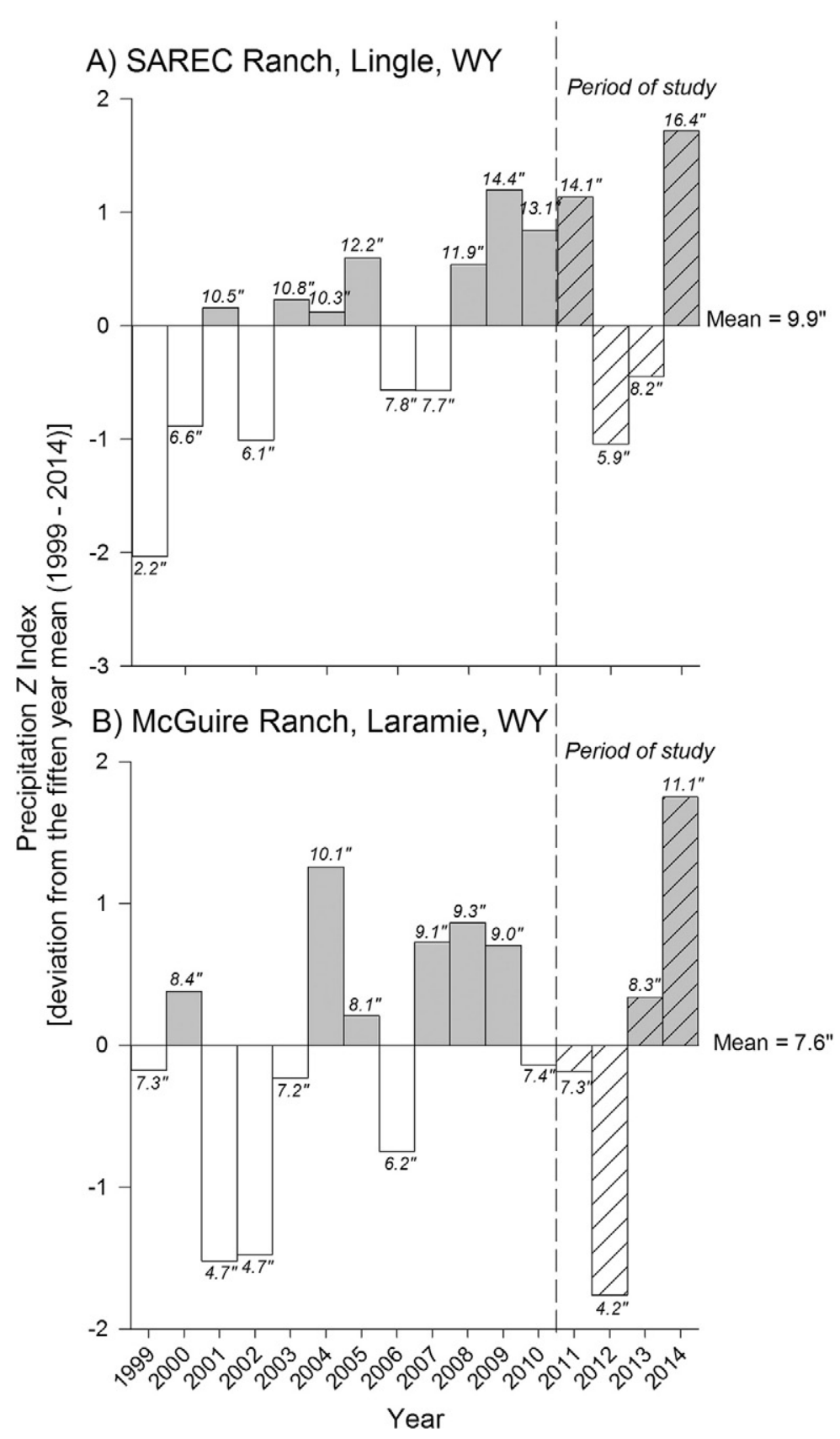

Figure 1. Annual deviation from the mean cumulative precipitation based on standardized Z index relative to the fifteen year mean (1999-2014) for (A) SAREC ranch northwest of Lingle, Wyoming, USA, using the Torrington, Wyoming, weather station (ID:KWYTORR13; 42.06 N 104.18 W; 4,094'); and (B) McGuire ranch north of Laramie, Wyoming, using the Laramie, Wyoming, weather station (ID:KWYLARAM13; 41.34 ${ }^{-} \mathrm{N} 105.61^{-} \mathrm{W}^{\prime}$ 7,140').

predicting reduced WW along the drought gradient was significant $^{\text {vi }}$ and highly correlative ${ }^{\text {vii }}$ in all cases (see Table 1 ). The twofold difference in slope between the two locations is also an indication of how the native plant community optimizes forage quality and quantity relative to different amounts of precipitation, a reflection of the differences in plant communities and precipitation regimes. We contend that the plant community at each ranch uniquely optimizes forage quality at different levels of precipitation because different ecologic sites have different beta

\footnotetext{
vi $P \leq 0.05$.

vii $r^{2}=0.91$ to 0.97 .
}

diversity and directional trajectory along the drought severity gradient. ${ }^{8}$ This variability may influence the genetic potential for cattle growth with optimization at these different peaks. For example, considering steer $\mathrm{WW}$ and $\mathrm{ADG}$ at both locations were similar in 2014 ( $547 \mathrm{lb}$ and $546 \mathrm{lb}$ adjusted WW; 2.61 and $2.60 \mathrm{lb}$ ADG at SAREC and McGuire, respectively); but maximum growing season precipitation totals were different (16.4 and 11.1 inches, respectively).

\section{Economic Loss}

When comparing the 2012 drought year to the 4-year average, SAREC calves had a $\$ 49$ to $\$ 63$ per head loss, and 


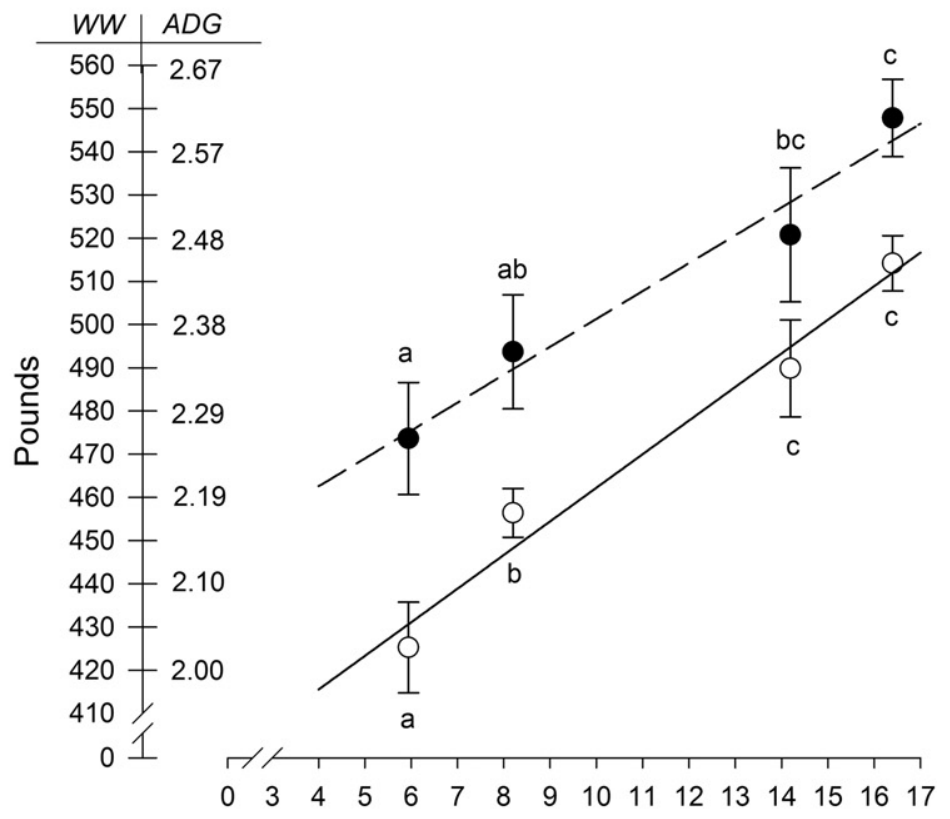

B) McGuire Ranch, Laramie, WY

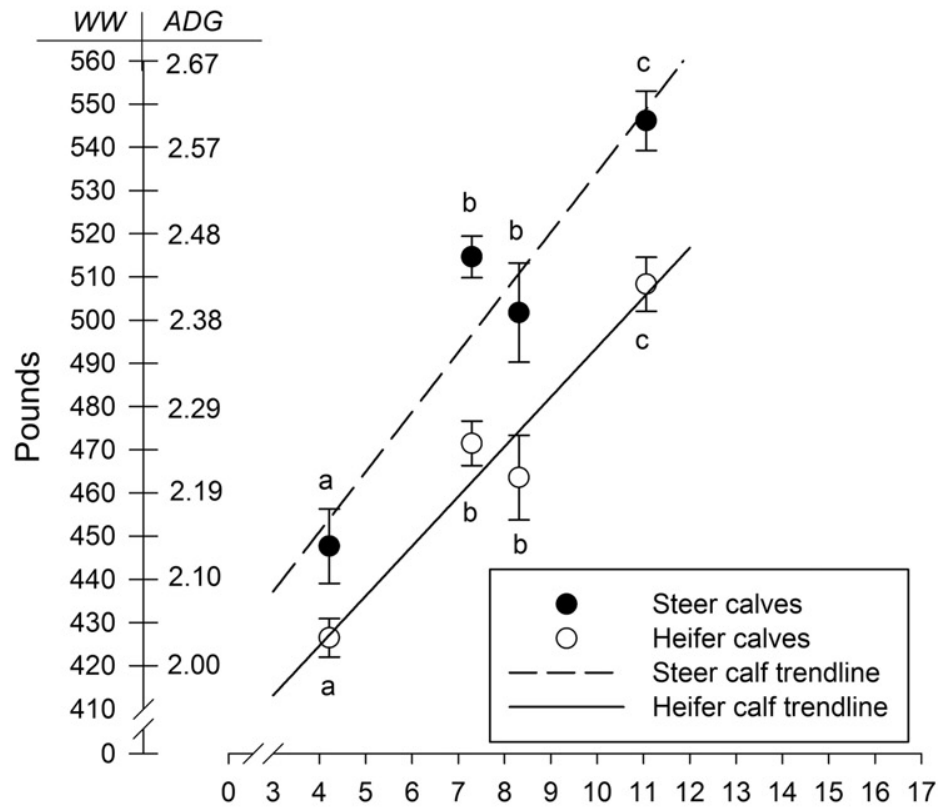

Cumulative precipitation (Jan 1 - Oct 1 ; inches)

Figure 2. Mean and standard error of the adjusted weaning weights (WW), average daily gain (ADG) by calf sex, and growing season precipitation at (A) SAREC ranch northwest of Lingle, WY; and (B) McGuire ranch north of Laramie, Wyoming. Cattle data and precipitation data represent 2011-2014. Precipitation is cumulative from January 1 to October 1 annually.

McGuire calves had a $\$ 79$ to $\$ 92$ per head loss, depending on calf sex (Table 2). SAREC experienced a total herd loss of $\$ 2,454$, attributed to a reduction of $1,251 \mathrm{lb}$ of weaned beef. McGuire experienced a total herd loss of $\$ 14,836$, attributed to a reduction of 7,502 $\mathrm{lb}$ of weaned beef. When quantifying these categories of losses for each one-inch precipitation deficit, SAREC calves had a $\$ 12$ to $\$ 15$ per head loss per one-inch reduction, and McGuire calves had a $\$ 23$ to $\$ 27$ per head loss per one-inch reduction, depending on calf sex (see Table 2). The SAREC herd lost $\$ 613$ and the McGuire herd lost $\$ 4,363$ for each inch of precipitation deficit. The two ranches could expect a loss of $313 \mathrm{lb}$ and 2,206 lb of weaned beef, respectively, for each inch of precipitation deficit (see Table 2). Two major drivers of the differences in economic loss are the different base herd size -44 head at SAREC and 174 head at McGuire-and the two-fold steeper slope for the precipitation/WW relationship at McGuire (see Table 1). 
Table 1. Linear regression of steer and heifer adjusted 210 day weaning weights (WW) and average daily gain (ADG) at the University of Wyoming SAREC ranch northwest of Lingle, Wyoming, and McGuire ranch north of Laramie, Wyoming, from 2011 to 2014.

\begin{tabular}{|l|l|l|l|l|l|l|l|}
\hline Ranch & $\begin{array}{l}\text { Calf } \\
\text { sex }\end{array}$ & $\begin{array}{l}\text { WW } \\
\text { slope }\end{array}$ & $\begin{array}{l}\text { WW } \\
\text { intercept }\end{array}$ & $\begin{array}{l}\text { ADG } \\
\text { slope }\end{array}$ & $\begin{array}{l}\text { ADG } \\
\text { intercept }\end{array}$ & $\boldsymbol{r}^{2}$ & P value \\
\hline SAREC ranch & Steers & $6.45 \mathrm{x}$ & 437 & $0.03 \mathrm{x}$ & 2.08 & 0.97 & $<0.02$ \\
\hline SAREC ranch & Heifers & $7.77 \mathrm{x}$ & 385 & $0.04 \mathrm{x}$ & 1.83 & 0.97 & $<0.02$ \\
\hline McGuire ranch & Steers & $13.85 \mathrm{x}$ & 396 & $0.07 \mathrm{x}$ & 1.88 & 0.91 & $<0.05$ \\
\hline McGuire ranch & Heifers & $11.51 \mathrm{x}$ & 379 & $0.06 \mathrm{x}$ & 1.80 & 0.94 & 0.03 \\
\hline
\end{tabular}

\section{Management Implications}

With the prediction that climate change is going lead to greater drought frequency and severity, especially in the interior rangelands of North America, it is important to understand the consequences for rangeland livestock production. The information in our study underscores the realization that not only could carrying capacity due to forage quantity be reduced, but forage quality and cow-calf performance, as measured by pounds of weaned and marketed beef from rangelands, could be reduced as well. Ranchers are advised to anticipate these additional consequences before calves get to the working pens and scales if cumulative precipitation through the growing season is lower than average.

Extended drought events in many of the high cattle producing areas of the nation have led to a decrease in total cattle numbers and a subsequent increase in market prices during this study period, rising from $\$ 110 / \mathrm{cwt}$ in 2011 to $\$ 140 /$ cwt in 2014 . ${ }^{9}$ Consequently, demand for beef has remained strong, but the supply has not yet recovered from the reductions in inventory that occurred at the beginning of the drought period. The supply/demand tradeoff from this drought-induced trend is that replacement heifer prices are also at an all-time high due to heifer retention and demand - a barrier to herd expansion and recovery after the drought. ${ }^{10}$

If the projected reductions in spring and summer precipitation for the Great Plains and western United States occur, these net negative effects could compound. ${ }^{11}$ Although we did not directly measure forage quality in our study, McCuistion et al. ${ }^{5}$ reported that for every one-inch reduction in monthly precipitation, forage crude protein is reduced by $2 \%$ to $3 \%$ in the spring and fall. Therefore, it may also be prudent to supplement appropriately stocked cow-calf herds with protein during drought to enhance consumption and digestibility of low-quality forage as a strategy to offset the predicted reductions in calf performance, provided adequate

Table 2. Economic losses of drought for the 2012 drought compared with the 4-year (2011-2014) average and losses per inch of precipitation deficit for the University of Wyoming SAREC and McGuire ranches. Price estimates based on November 10, 2014, USDA-Wyoming market news reports from Torrington, Wyoming, and Riverton, Wyoming, for medium and large \#1 feeder steers and heifers. Base herd numbers of 44 and 174 heads used for the two ranches, respectively. Price assumptions do account for the tradeoff between calf weight (cwt) and price (i.e., price slide) but do not account for supply-induced price reductions that are expected during drought.

\begin{tabular}{|c|c|c|c|c|c|c|}
\hline \multirow[b]{2}{*}{$\begin{array}{l}\text { Ranch-calf } \\
\text { sex/herd }\end{array}$} & \multicolumn{3}{|c|}{ 4-year mean versus 2012 drought } & \multicolumn{3}{|c|}{ Per inch of precipitation deficit } \\
\hline & $\begin{array}{l}\text { \$/head } \\
\text { loss }\end{array}$ & $\begin{array}{l}\$ / \text { herd } \\
\text { loss }\end{array}$ & $\begin{array}{l}\text { \# beef } \\
\text { loss }\end{array}$ & $\begin{array}{l}\text { \$/head } \\
\text { loss }\end{array}$ & $\begin{array}{l}\$ / \text { herd } \\
\text { loss }\end{array}$ & $\begin{array}{l}\text { \# beef } \\
\text { loss }\end{array}$ \\
\hline SAREC steers & $\$ 48.78$ & $\$ 1,073.21$ & 568 & $\$ 12.20$ & $\$ 268.30$ & 142 \\
\hline SAREC heifers & $\$ 62.77$ & $\$ 1,380.85$ & 684 & $\$ 15.70$ & $\$ 345.21$ & 171 \\
\hline SAREC herd & & $\$ 2,454.07$ & 1,251 & & $\$ 613.52$ & 313 \\
\hline McGuire steers & $\$ 91.59$ & $\$ 7,968.42$ & 4,097 & $\$ 26.94$ & $\$ 2,343.65$ & 1,205 \\
\hline McGuire heifers & $\$ 78.94$ & $\$ 6,867.83$ & 3,405 & $\$ 23.22$ & $\$ 2,019.95$ & 1,001 \\
\hline McGuire herd & & $\$ 14,836.26$ & 7,502 & & $\$ 4,363.61$ & 2,206 \\
\hline
\end{tabular}


amounts of low-quality forage are available. ${ }^{12}$ It will also become important to develop new strategies to mitigate these drought-induced losses, such as enhancing vegetation heterogeneity ${ }^{13}$ or considering beef cattle breeds or crossbreeds more adapted to drought stress. In a study by Frisch, ${ }^{14}$ Bos taurus breeds were compared with Bos taurus $x$ Bos indicus crossbreeds under drought conditions. The crossbred cattle did not have as high a gain in the good years compared with purebred Bos taurus, but they were less inclined to have debilitating losses in the drought years. ${ }^{14}$ Drought may also lead to a shift in cattle diet composition due to greater shrub selection as grasses and forbs become less available. ${ }^{12} \mathrm{~A}$ similar study also demonstrated a reduction in yearling heifer weight gains and forage intake in the latter part of the season during a drought year in Oregon. ${ }^{12}$ An additional adaptive management strategy is to adjust stocking rates based on precipitation in the current growth season. ${ }^{15}$

\section{Conclusions}

We have summarized data from two Wyoming ranches to better understand drought-induced reductions of calf WW and ADG. These ranches are different in plant community and grazing management but provide case studies relevant to the northern Great Plains and the intermountain regions of the Rocky Mountains. These results can assist ranchers in anticipating consequential losses in WW and ADG caused by drought. As ranchers continue to deal with drought, a challenge as old as pastoralism and animal agriculture on rangelands itself, projecting the potential consequences of escalating drought prevalence in the western Great Plains will inform strategies to mitigate these losses. By quantifying these losses, we have also provided important data for ranchers to use when seeking compensation for drought-induced losses that may not be limited to herd liquidation. Our documentation of these negative consequences in a peer-reviewed format provides a reference for ranchers and consultants in making drought-insurance decisions and documenting losses that affect the bottom line.

\section{Acknowledgements}

This work was made possible by the University of Wyoming Agriculture Experiment Station staff that has managed the cow-calf herds during this period. We thank Ronny Scasta for input from a cattleman's perspective. Cattle management follows the guidelines stated in the Guide for the Care and Use of Agricultural Animals in Research and Training.

\section{References}

1. Cook, E.R., R. Seager, M.A. Cane, and D.W. Stahle. 2007. North American drought: reconstructions, causes, and consequences. Earth-Science Reviews 81(1):93-134.
2. Ponce, V.M., R.P. Pandey, and S. Ercan. 2000. Characterization of drought across climatic spectrum. Journal of Hydrologic Engineering 5(2):222-224.

3. Lal, R., J.A. Delgado, J. Gulliford, D. Nielsen, C.W. Rice, AND R.S. VAN Pelt. 2012. Adapting agriculture to drought and extreme events. Journal of Soil and Water Conservation 67(6):1621A-166A.

4. Bastian, C.T., S. Mooney, A.M. Nagler, J.P. Hewlett, S.I. Paisley, M.A. Smith, W.M. Frasier, and W.J. Umberger. 2006. Ranchers diverse in their drought management strategies. Western Economics Forum 5(2):1-8.

5. McCuistion, K., M. Grigar, D.B. Wester, R. Rhoades, C. Mathis, and L. Tedeschi. 2014. Can we predict forage nutritive value with weather parameters? Rangelands 36(1):2-9.

6. Orton, K. 2014. USDA-WY Department of Ag Market News. United States Agricultural Marketing Service. Available at: www. ams.usda.gov. Accessed 1 December 2014.

7. HolecheK, J.L. 1996. Drought and low cattle prices: hardship for New Mexico ranchers. Rangelands 18:11-13.

8. Scasta, J.D., AND B.S. Rector. 2014. Drought and ecological site interaction on plant composition of a semi-arid rangeland. Arid Land Research and Management 28(2):197-215.

9. NAss, 2015. National Agriculture Statistics Survey, National Statistics for Cattle. Available at: http://www.nass.usda.gov/ Statistics_by_Subject2015 Accessed 1 April 2015.

10. CARrico, J. 2015. Cattle inventory increase not expected. High Plains/Midwest Ag Journal. Available at: http://www.hpj.com/ livestock/cattle-inventory-increase-not-expected-yet/ article_483b3db8-becd-11e4-8674-2b070fb3594e.html. Accessed 1 April 2015.

11. NCA, 2014. National Climate Assessment. Available at: http:// nca2014.globalchange.gov/report/our-changing-climate/ precipitation-change\#narrative-page-165682014 Accessed 1 December 2014.

12. Holechek, J.L., And M. Vavra. 1983. Drought effects on diet and weight gains of yearling heifers in northeastern Oregon. Journal of Range Management 36(2):227-231.

13. Allred, B.W., J.D. Scasta, T.J. Hovick, S.D. Fuhlendorf, and R.G. Hamilton. 2014. Spatial heterogeneity stabilizes livestock productivity in a changing climate. Agriculture, Ecosystems Eं Environment 193:37-41.

14. FrISCH, J.E. 1973. Comparative drought resistance of Bos indicus and Bos taurus crossbred herds in central Queensland. 2. Relative mortality rates, calf birth weights, and weights and weight changes of breeding cows. Animal Production Science 13(61):117-126.

15. Díaz-Solís, H., W.E. Grant, M.M. Kothmann, W.R. Teague, AND J.A. DíAz-GarCíA. 2009. Adaptive management of stocking rates to reduce effects of drought on cow-calf production systems in semi-arid rangelands. Agricultural Systems 100(1):43-50.

Authors are Assistant Professor, Department of Ecosystem Science and Management (Scasta, jscasta@uwyo.edu),Undergraduate Student, Department of Ecosystem Science and Management (Windh), Beef Unit Manager, Laramie Research and Extension Center, Agriculture Experiment Station, Laramie, WY (Smith), Farm Manager, James C. Hagemen Sustainable Agriculture Research and Education Center (SAREC), Agriculture Experiment Station, Lingle, WY (Baumgartner), University of Wyoming, Laramie, WY 82071, USA. 